DOI https://doi.org/10.36059/978-966-397-241-1-20

Тітаренко С. A.

кандидат педагогічних наук,

доцент кафедри дошкільної педагогіки і психології

Глухівський національний педагогічний університет імені

Олександра Довженка

м. Глухів, Сумська область

\title{
РОЗВИТОК КОМУНІКАБЕЛЬНОСТІ У ДІТЕЙ СТАРШОГО ДОШКІЛЬНОГО ВІКУ ЗАСОБОМ ГРИ
}

Обгрунтовано актуальність проблеми розвитку комунікабельності дітей старшого дошкільного віку засобом гри. Висвітлено стан розробленості проблеми комунікабельності в психологопедагогічній літературі. Представлено порівняння термінів «комунікабельність» та «комунікативність». Подано загальну характеристику та особливості розвитку комунікабельності у дітей старшого дошкільного віку. Схарактеризовано види ігрової діяльності та їх обгрунтовано їх вплив на розвиток комунікабельності у дітей старшого дошкільного віку. Обгрунтовано основні причини, які впливають на зниження або повну відсутність комунікативних навичок у дітей дошкільного віку.

\section{Вступ}

Закон України «Про дошкільну освіту», передбачає дослідження низки психолого-педагогічних проблем, серед яких чільне місце посідає проблема комунікативно-мовленнєвого розвитку дошкільника [21].

Через швидкий темп життя у дитини мають формуватися вміння швидко входити в дитячий колектив, адаптуватися до нових умов життя. Найбільше ця проблема стосується дітей старшого дошкільного віку, адже через деякий час перебування у закладі освіти вони мають змінити дитячий колектив $3 Д 0$ на новий колектив - у першому класі школи. Однією з умов успішної адаптації дитини до нового середовища $є$ їі вміння до спілкування, тобто комунікабельність.

Варто пам'ятати про те, що уміння встановлювати контакт 3 оточуючими формується в дитинстві, якщо потрібні навички 
комунікації не виробилися в дитинстві, то в дорослому житті людині буде некомфортно та важко під час контактування 3 кимось. Важливою частиною дорослішання дітей $\epsilon$ їх участь в колективних іграх, діти 3 проблемами комунікабельності можуть відчувати труднощі під час таких ігор, їм може бути важко ввійти в контакт зі своїми однолітками.

Спілкування дітей 3 однолітками - одна 3 найважливіших категорій розвитку особистості. Від того, на скільки дитина навчиться комунікувати, взаємодіяти з оточуючими, залежатиме ії успіх у подальшому житті. Саме від рівня комунікабельності залежатиме те, наскільки впевнено вона буде почувати себе в школі, закладі вищої освіти, на роботі і у будь-якому колективі взагалі.

Психолого-педагогічні дослідження з проблем спілкування, перш за все, пов'язані з іменами Б. Ананьєва, Л. Виготського, С. Рубінштейна, О. Леонтьєва, які розглядали спілкування як важливу умову психічного розвитку людини, iї соціалізації та індивідуалізації, формування особистості [15].

Дослідженням проблеми спілкування за кордоном займалися Дж. Боулбі, 3. Фрейд, Р.Спітц та інші. У працях М. Щелованова відображені проблеми взаємодії дорослого і дитини. Праці таких вчених, як С. Михальська, Н. Саліван, А. Фабер присвячені впливу сімейного виховання на розвиток спілкування дитини.

у науковій літературі представлено багато досліджень, спрямованих на визначення сутності комунікації, комунікативної компетентності, комунікативних умінь, комунікативної культури та навичок, розкриття їх основних функцій (Б. Андрушків, I. Мартиненко, А. Бескоровайна, Л. Кайдалової, Л. Кроль, Г. Васьківська, В. Яцук, С. Максименко, А. Панфілова, Г. Попов, та ін.), приділяється велика увага обгрунтуванню моделі ефективної комунікації (Г. Балл, В. Галузяк, Ю. Ємельянов, Р. Кричевський, Л. Орбан-Лембрик та ін.), аналізу суспільно-психологічних аспектів комунікації (Л. Карамушка, Т. Титаренко, Ю. Швалб та ін.) тощо.

Проблеми розвитку комунікабельності у дітей дошкільного віку досліджуються у працях таких науковців Л. Виготського, I. Кона, Л. Стрілецької, А. Кошельової, О. Шаграєвої. Таким дослідниками як М. Лісіна, А. Рузська, Л. Галігузова та інші, була розроблена концепція комунікативної діяльності, в рамках якої вивчалося спілкування дитини з однолітками.

Як відомо, у дітей дошкільного віку ігрова діяльність $є$ провідною. Тому вихованцям набагато краще, а також легше засвоювати нові дії, 
знання у процесі гри. Тому розвиток комунікабельності у дітей старшого дошкільного віку буде відбуватися ефективніше саме у процесі ігрової діяльності. Під час гри дошкільники оволодівають вміннями взаємодіяти та спілкуватися з оточуючими. Гра підвищує активність дитини, а також вдовольняє соціальні потреби та особисті інтереси. М. Айзенбарт зазначає, що використання ігор дає змогу реалізувати низку важливих завдань 3 розвитку комунікабельності [1].

Таким чином, проблема розвитку комунікабельності дітей старшого дошкільного віку засобом гри без сумніву є актуальною.

\section{1. Стан розробленості проблеми комунікабельності в психолого-педагогічній літературі}

Людині важко жити, навчатися, працювати, задовольняти власні потреби, не вступаючи у взаємодію 3 іншими. Спілкування $\epsilon$ необхідною соціальною та важливою духовною потребою людства, а також, важливим джерелом його розумового розвитку в онтогенезі.

У процесі спілкування людина себе реалізує, обмінюється інформацією зі своїм співрозмовником, розглядає різні питання, вирішує проблеми. Саме у процесі взаємодії виявляється людська природа.

Поняття спілкування вживається у психологічній літературі в різних значеннях [9]:

- як обмін думками, почуттями, переживаннями (Л. Виготський, С. Рубінштейн);

- як один з різновидів людської діяльності (Б. Ананьєв, М. Коган, І. Кон, О. Леонтьєв);

- як специфічна соціальна форма інформаційного зв'язку (Л. Рєзников);

- $\quad$ як взаємодія стосунки між суб'єктами, які мають діалогічний характер (Г. Андрєєва, К. Платонов).

За педагогічним словником, спілкування - це складна взаємодія людей, в якій здійснюється обмін думками, почуттями, переживаннями, способами поведінки, звичками, а також задовольняються потреби особистості в підтримці, солідарності, співчутті, дружбі тощо [8].

Спілкування охоплює всі галузі людської діяльності та людського буття. У процесі живого спілкування співрозмовники здатні впливати один на одного. Під час спільної діяльності людям необхідно спілкуватися, адже результат такої діяльність не буде позитивним, 
якщо між ії виконавцями не буде налагоджено контакт і не існуватиме взаєморозуміння. Незмінним у спілкуванні $€$ наявність партнерів, ситуації, а також завдань спілкування. Характер спілкування постійно змінюється, це залежить від характеристики вище зазначених складників. Відповідно до цього комунікабельність має на меті розвивати уміння самооцінки, орієнтації у ситуації спілкування, меті спілкування, у самому собі та потенціалі співрозмовника.

Проблема комунікабельності або ж уміння спілкуватися, постійно цікавила людей, вивчення цієї проблеми почалося ще 3 античних часів. Суспільство постійно змінюється та розвивається, разом з ним змінюється і уявлення про комунікабельність. Кожен новий етап висуває різні вимоги до особистості. На кожному з цих етапів комунікабельність розглядається по різному. Також комунікабельність досліджують через необхідність пошуку ефективних засобів побудови взаємодії, необхідність в нових знаннях і вміннях в системі міжособистісних стосунків. Таким чином, комунікабельність не слід розглядати як кінцеву та сталу характеристику індивіда.

Дістаючи задоволення від спілкування, комунікабельна людина деколи діє у власних інтересах, не викликаючи ніяких (позитивних, негативних) емоцій у співрозмовника, що блокує контакт.

У уявленні людей, комунікабельність має найбільшу значущість для організації процесу спілкування та пов’язана з особистісною комунікативністю.

Комунікативність - сукупність істотних, відносно стійких властивостей особистості, що сприяють успішному прийому, розумінню, засвоєнню, використанню й передаванню інформації [6].

В.Кан-Калик характеризує комунікативність як багатопланове явище, що поєднує ряд компонентів, серед яких особливе значення мають комунікабельність, соціальна спорідненість, альтруїстичні тенденції [14].

Комунікабельність визначається як здатність отримувати задоволення від процесу спілкування з оточуючими. Соціальна спорідненість - бажання бути серед інших людей. Альтруїстичні емоції пов'язані з бажанням радувати людей, з якими відбувається процес спілкування.

Комунікабельність може виявлятися через: гіперкомунікабельність та гіпокомунікабельність. Гіперкомунікабельність - риса особистості людини, що зумовлює такий рівень організації процесу спілкування, який характеризується великою кількістю поверхових контактів, у яких центром комунікації є ця людина [23]. 
Гіперкомунікабельні люди дуже люблять говорити і майже нікому іншому не дають можливість висловитися, така їхня надокучливість втомлює, нетактовність пригнічує. Вони не вміють слухати, не вміють розраховувати час, вони безтурботні та деколи безвідповідальні.

Гіпокомунікабельність - риса особистості, що зумовлює такий рівень організації процесу спілкування, який характеризується невеликою кількістю контактів, пасивною позицією людини у комунікативному акті [23].

Гіпокомунікабельні люди не виявляють бажання до спілкування, не виявляють ініціативи у спілкування, хочуть швидше закінчити бесіду. Людям з гіпокомунікабельністю не варто йти працювати у ті сфери де без вміння спілкуватися з оточуючими неможливо.

Поняття «комунікабельність» походить від латинського communico - з'єдную, повідомляю. У психолого-педагогічній літературі $€$ велика кількість визначень поняття «комунікабельність». За психологічним словником, комунікабельність - це потреба і здатність особистості до спілкування 3 іншими людьми, товариськість. Для комунікабельної людини характерна легкість у налагодженні контактів, здатність і уміння не розгубитись при спілкуванні в різних ситуаціях [22]. В. Кабрін розуміє комунікабельність як інтегральну характеристику особистості, іiї цілісний морально-творчий потенціал, своєрідну багатогранну тенденцію, що забезпечує життєздатність особистості [5]. О. Денисенко дає таке визначення комунікабельності - це риса особистості, здатність ії до спілкування з іншими людьми, товариськість [9]. І. Юсупов визначив комунікабельність як психічну готовність людини до організаторсько-комунікативної діяльності.

На думку А. Мудрика, комунікабельність $\epsilon$ добре розвинутим, стійким прагненням особистості до контактів з оточуючими, яке співвідноситься зі швидкістю їх встановлення [19]. Це вміння правильно розуміти людину і ставити себе на її місце, гнучкість і делікатність, тактовність у спілкуванні, уміння слухати, спроможність підтримати іншого й стимулювати його на розвиток особистісних сил, уміння викликати довірливе ставлення до себе, організаційні здібності.

Дуже часто поняттяь «комунікабельність» ототожнюють 3 поняттям «комунікативність». Пропонуємо звернути увагу на таблицю 1. для порівняння термінів «комунікабельність» та «комунікативність». 
Таблиця 1

Порівняння термінів «комунікабельність» та «комунікативність» [7]

\begin{tabular}{|c|c|c|}
\hline Критерій & Комунікабельність & Комунікативність \\
\hline Носій & $\begin{array}{l}\text { Люди, які схильні до спілкування } \\
\text { або отримали підготовку в } \\
\text { області встановлення контактів. }\end{array}$ & $\begin{array}{l}\text { Люди-власники особливих } \\
\text { характерологічних якостей, а } \\
\text { також люди, які прагнуть до } \\
\text { удосконалення своїх цінностей, } \\
\text { установок, ідеалів, інтересів. }\end{array}$ \\
\hline Сутність & $\begin{array}{l}\text { Вміння викликати симпатію, } \\
\text { зав'язати дружні відносини, } \\
\text { заручитися підтримкою } \\
\text { співрозмовника, }\end{array}$ & $\begin{array}{l}\text { В психології - особлива } \\
\text { здатність; в менеджменті - } \\
\text { ключова компетенція. }\end{array}$ \\
\hline Складники & $\begin{array}{l}\text { Складові зазвичай не } \\
\text { виділяються. Комунікабельність } \\
\text { сама є частиною будь-якого виду } \\
\text { активності }\end{array}$ & $\begin{array}{l}\text { Поєднання особливого виду } \\
\text { активності, емоційної } \\
\text { реактивності, впевненості, } \\
\text { вміння утримувати } \\
\text { комунікативний об'єкт }\end{array}$ \\
\hline $\begin{array}{l}\text { Виконувані } \\
\text { функції }\end{array}$ & $\begin{array}{l}\text { Встановлення поверхневих } \\
\text { контактів }\end{array}$ & $\begin{array}{l}\text { Передача інформації, емоційне } \\
\text { вираження, мотивація, } \\
\text { контроль та ін. }\end{array}$ \\
\hline 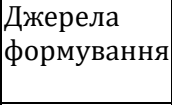 & Спеціальна література; тренінги & $\begin{array}{l}\text { Життєвий досвід; мистецтво } \\
\text { спілкування; загальна ерудиція; } \\
\text { спеціальні наукові методи }\end{array}$ \\
\hline $\begin{array}{l}\text { Особливості } \\
\text { розвитку }\end{array}$ & $\begin{array}{l}\text { Починається із усвідомлення } \\
\text { проблем у професійній діяль- } \\
\text { ності або особистому зростанню } \\
\text { та часто зводиться до вивчення } \\
\text { найбільш поширених, але не } \\
\text { завжди відповідних } \\
\text { особливостям особистості і } \\
\text { виконуваних нею завдань. } \\
\end{array}$ & $\begin{array}{l}\text { Починається з формування у } \\
\text { людини такої спрямованості, } \\
\text { при якій цінність людського } \\
\text { спілкування знаходиться на } \\
\text { периферії, а в центрі - ціннісні } \\
\text { орієнтації }\end{array}$ \\
\hline \begin{tabular}{|l|} 
Потреба в \\
додаткових \\
навичках
\end{tabular} & $\begin{array}{l}\text { Незначна, обмежується поверх- } \\
\text { невим аналізом обстановки та } \\
\text { особистісних особливостей спів- } \\
\text { розмовника, які не утримуються } \\
\text { в пам'яті надовго і часто служать } \\
\text { предметом маніпулювання }\end{array}$ & $\begin{array}{l}\text { Загальна ерудиція, знання } \\
\text { філології, основ маркетингу та } \\
\text { психології, повна інформація } \\
\text { про діяльність своєї організації, } \\
\text { а також про ту аудиторію, на } \\
\text { яку спрямовується діяльність }\end{array}$ \\
\hline $\begin{array}{l}\text { Результат } \\
\text { прояву в } \\
\text { умовах } \\
\text { організації }\end{array}$ & $\begin{array}{l}\text { Непередбачуваний: в разі вда- } \\
\text { лого прояву - підвищення рівня } \\
\text { ефективності діяльності орга- } \\
\text { нізації, пожвавлення відносин; в } \\
\text { разі невдалого прояву - } \\
\text { зниження продуктивності, чуток, } \\
\text { пліток, малозначущих розмов, в } \\
\text { тому числі за межами організації }\end{array}$ & $\begin{array}{l}\text { Нормалізує соціально- } \\
\text { психологічний клімат в } \\
\text { колективі, залишає позитивне } \\
\text { враження про організацію та } \\
\text { піднімає ї̈ на високий рівень в } \\
\text { рейтингах. }\end{array}$ \\
\hline
\end{tabular}


Часто комунікабельність прирівнюють до товариськості. Усім доводилося хоч один раз у своєму житті зустріти товариську людину. 3 такою людиною з задоволенням спілкуються, часто біля неї велика кількість людей. Про таку людину можна сказати, що вона комунікабельна, адже їй вдається встановити дружні зв'язки 3 оточуючими. Але ж комунікабельність і товариськість не $\epsilon$ синонімами. У першу чергу відмінність цих понять у тому, що комунікабельній людині не все одно, як її сприймають співрозмовники. Комунікабельні люди вміють красиво і правильно розмовляти, а товариська людина може говорите перше, що спаде їй на думку, може вживати слова-паразити і ненормативну лексику, зовсім не думаючи про те як її сприймає співрозмовник.

Комунікабельність - ширше поняття, яке включає не лише уміння спілкуватися на певну тему, але й уміння вести бесіду у формі конструктивного діалогу з будь-якою людиною.

Вивчаючи структуру комунікативності особистості, Ю.Ханін виділяє три основні їі компоненти [26]:

1) потреба у спілкуванні;

2) емоційний стан до, під час і після спілкування;

3) комунікативні вміння і навички (певні способи спілкування, що допомагають особистості активно входити в процес міжособистісного спілкування).

У структурі комунікативних здібностей вчені виділяють низку умінь, що позитивно впливають на процес взаємодії [12]: вміння слухати і розуміти інших, передавати достовірну інформацію, сприймати й оцінювати ситуацію спілкування, прогнозувати іï розвиток; вміння емоційно відгукуватись, використовувати зворотній зв'язок; вміння переконувати, тактовність, дисциплінованість, уважність, ввічливість, емпатійність, контактність, ініціативність; вимогливість не лише до інших, а й до себе; здатність до ідентифікації та персоналізації.

Проаналізувавши дослідження багатьох вчених, у тому числі й Ф. Гоноболіна, Н. Кузьміної, О.Леонтьєв виділив, описав та представив комунікативні вміння в певній системі [15]:

1) вольові якості (здатність керувати своєю поведінкою);

2) уважність (спостережливість, гнучкість);

3) навички соціальної перцепції (вміння розуміти обличчя);

4) здатність не лише бачити, а й розуміти психічні стани розмовника (емпатія);

5) вміння оптимально будувати своє мовлення з психологічної точки зору (навички мовленнєвого спілкування);

6) вміння мовного та немовного контакту. 
За О. Денисенко комунікабельність проявляється в таких уміннях [9]: в умінні правильно сприймати і оцінювати людей, а саме: індивідуальні характерологічні особливості, цілі, мотиви, наміри, стани; в умінні правильно оцінювати життєві ситуації і діяти з їх урахуванням; в умінні обрати такі стилі, засоби, прийоми спілкування, які б з мінімальними затратами приводили до бажаної мети спілкування; в умінні співчувати людям; у пластичності мислення, що допомагає у виборі ефективних засобів переконання i здійснення впливу на співрозмовника.

Кожне з зазначених умінь безумовно важливе для позитивного впливу на процес взаємодії людей. Комунікабельність проявляється в здатності реалізовувати функції впливу, передачі інформації, в здатності успішно вирішувати комунікативні завдання, а вище перераховані уміння допомагають реалізувати ці функції.

Як показали роботи Л. Виготського, О. Леонтьєва, О. Лурія та інших вчених, людські форми поведінки, мовлення, психічні функції i властивості не даються дитині при народженні. Вони формуються під вирішальним впливом цілеспрямованого виховання і навчання, умов життя дитини в соціумі. Комунікабельність не $є$ винятком, з навичками комунікабельності не народжуються, їх набувають. Комунікабельність формується в процесі життя й діяльності людини в соціальній групі. Передумови розвитку комунікабельності в темпераменті, особливості якого ми отримуємо у спадок від обох батьків, фундамент комунікабельності закладається в перші роки життя дитини батьками, вихователями, вчителями. Головні ж основи розвитку здібностей людини до спілкування формуються в шкільні роки. Вже в початковій школі дитина намагається впливати на однолітків і дорослих в принципово нових формах у порівнянні з дошкільним віком. Цьому сприяє еволюція дитячих вмінь та навичок комунікабельності, компетентності та навичок партнерської орієнтації [9].

Комунікабельність формує людину, а потім стає засобом, який забезпечує успіх особистості в усіх сферах її життєдіяльності.

Оскільки навички комунікабельність формуються протягом життя то, відповідно до цього, їх можна розвивати. Працювати над розвитком власної комунікабельності пропонують у двох напрямах:

1. Подолання психологічного дискомфорту від вимушеного спілкування.

2. Виконання вправ на риторику.

Безумовно розвивати комунікабельність можливо лише у процесі взаємодії з людьми. Неможливо розвинути комунікабельність, 
виконуючи певні вправи та читаючи спеціальну літературу. Після читання літератури людина отримує лише теоретичні знання, але ж важливо не лише володіти цими знаннями, але й уміти їх застосовувати. Лише реальне спілкування допоможе людині розвинути власну комунікабельність.

Поняття «комунікабельність» вміщує у собі здібності до спілкування та нахил до спілкування. Відповідно до цих факторів комунікабельна людина повинна вміти і хотіти спілкуватися 3 іншими. Не можна назвати людину комунікабельною якщо вона: вміє спілкуватися, але не прагне це робити; прагне до спілкування, їй подобається спілкуватися, але вона не вміє це робити.

Комунікабельні люди - відкриті до спілкування, мають свою думку, вони гарні оповідачі, володіють різними жестами, інтонаціями, вмінням перевтілюватися. Такі люди не бояться першими починати бесіду. У спілкуванні з кимось комунікабельна людина може бути дуже чутливою до будь-яких змін. На усе сказане така людина реагує швидко та точно. Їй вдається зрозуміти усі інтонації у бесіді. Бесіда з комунікабельною людиною приємна та цікава. Комунікабельні люди толерантно ставляться до висловлювань інших людей, такі люди не намагаються тиснути своїм авторитетом, якщо з ними не згодні. Комунікабельні люди спостережливі: якщо тема розмови когось не влаштовує, вони делікатно переводять розмову в іншу площину. Посмішка, що виражає доброзичливість, $є$ одним 3 атрибутів комунікабельної людини.

У жодному разі бути комунікабельним не означає вміти багато говорити. Буває так, що людина дуже довго розповідає про своє життя, але в цей час вона не помічає, що люди які їі слухають стають роздратованими. Часто люди помилково вважають себе комунікабельними, лише через те, що вони прагнуть до спілкування, але ж цього прагнення мало, не слід забувати й про уміння спілкуватися та вступати в контакт. Щоб легко вступати в контакт, потрібно відчувати іншу людину, усвідомлювати результати своїх дій у спілкуванні, тобто мати здатність сприймати й розуміти іншого.

Уміти уважно вислухати таке ж важливе, як уміння говорити. Людям приємно спілкуватися з тими, хто їх дійсно слухає, а не пропускає все сказане повз вуха. Людина яка неуважно слухає, перебиває, насміхається 3 опонента може створити атмосферу дискомфорту. Зазвичай комунікабельна людина користується авторитетом в колективі та стає його лідером. 
У психології спілкування виділяються основні типи комунікабельності людей (розрізняються залежно від переваги мовленнєвих характеристик: домінантність, мобільність, ригідність, інтровертність) [25]: домінантний; мобільний; ригідний; інтровертний.

Домінантного співрозмовника важко сплутати з будь-яким іншим. Через декілька хвилин спілкування з таким співрозмовником виникає відчуття, що його «багато», що на вас «тиснуть». Такі люди не люблять щоб їх перебивали, говорять трішки голосніше за інших, бувають різкими. Якщо він схоче звернутися до будь-кого, він це зробить, навіть якщо доведеться когось перебити. Якщо такому співрозмовнику буде поставлено запитання то не факт, що він вважатиме за потрібне відповісти. Уході такої бесіди ви можете збільшувати дистанцію зі своїм партнером, але домінантна людина іiї буде скорочувати. Зазвичай домінантні співрозмовники вміють переконувати, вони гарні оратори, можуть швидко приймати рішення. Якщо ж обидва співрозмовники домінантні між ними може виникнути сварка та й домовитися їм буде важко [25].

Для мобільного співрозмовника відсутні труднощі у комунікації. Йому вдається легко входити у розмову, охоче спілкується, дуже часто змінює теми, навіть у непідходящий момент, у незнайомій компанії почуває себе досить впевнено. Мова досить швидка, деколи не зрозуміло що він говорить. Такий співрозмовник може перебивати, він любить поговорити. Довгі розповіді дратують мобільного співрозмовника. Цей тип $€$ одним 3 кращих для побутового спілкування.

Ригідному співрозмовнику потрібен деякий час щоб вступити у бесіду. Після етапу вступу такий співрозмовник чітко формулює свою позицію, він логічний, розсудливий. Ригідний співрозмовник спочатку дає не чіткі відповіді на запитання «можливо», «варто подумати». Такий партнер буде уважно слухати, його не можна перебивати так як і він не буде перебивати вас, розмовляє не поспішаючи, фрази формулює точно, може довго говорити про одне й те ж саме [25].

Інтровертний співрозмовник майже ніколи не буває ініціатором спілкування. Він сором'язливий, тихо розмовляє, терпляче ставиться до того, що його перебивають, не любить говорити під час присутності незнайомих людей. Може розгубитися якщо почує в свою сторону різкі та грубі фрази. Такий партнер намагається якомога рідше звертатися до оточуючих, бо вважає, що його слова, запитання будуть недоречними, але коли звертаються до нього то 
вів вважає, що зобов'язаний відповісти негайно. Для того, щоб спілкування з інтровертним співрозмовником було продуктивним його постійно необхідно підбадьорювати, вербально та невербально висловлювати свою повагу до нього, як до цікавого співрозмовника. Якщо інтроверта перебити то він може замовчати надовго [25].

Опрацювавши психолого-педагогічну та наукову літературу ми виділяємо такі перевагами комунікабельності: звільнення від комплексів; почуття впевненості в собі; можливість брати ситуацію під контроль у будь-якій ситуації; уміння у будь-яких обставинах знайти спільну мову з співрозмовником; можливість впливати на поведінку людей з метою досягнення власних цілей; відчуття щастя та задоволення від спілкування з людьми; наявність можливостей для самореалізації; уміння вирішувати конфліктні ситуації; незалежність від чужих думок [5; 9; 12; 25].

Саме комунікабельність людини впливає на створення позитивної емоційно-психологічної атмосфери спілкування з оточуючими, на характер взаємостосунків та стиль взаємодії між ними. Комунікабельність як складова комунікативності стає значущою за умови відчуття людиною соціальної спорідненості з оточенням, коли вона не протиставляє себе, свій досвід, а об'єднується зі співрозмовниками.

Отже, поняття «комунікабельність» почали досліджувати ще за часів античності, інтерес до цього поняття не зник і сьогодні. Багато вчених випускають нові посібники з розвитку комунікабельності, уміння спілкуватися, уміння йти на контакт. Не лише вітчизняні, але й зарубіжні вчені дійшли до того висновку, що бути комунікабельною людиною важливо для людей різних професій. Вчені розглядають важливість комунікабельності у різних сферах діяльності людини (діловій, педагогічній, торгівельній тощо), проводять дослідження з розвитку комунікабельності, пропонують велику кількість порад для її розвитку у людей різного віку.

\section{2. Загальна характеристика та особливості розвитку} комунікабельності у дітей старшого дошкільного віку

У житті людини постійно відбуваються зміни, щоб почувати себе комфортно вона повинна вміти пристосовуватися до них. Для того, щоб швидко адаптуватися до будь-яких змін важливо вміти спілкуватися. Спілкуватися дитина починає швидше ніж говорити. 3 кожним роком мовлення дитини розвивається, а уміння спілкуватися вдосконалюється. Ефективність спілкування, в першу чергу, залежить від навичок висловлювання думки у відповідній ситуації. 
Досліджуючи особливості спілкування дошкільників, 0. Запорожець і М.Лісіна ввели у науковий обіг поняття «комунікативна діяльність», ними були досліджені взаємозв'язки між спілкуванням та іншими видами дитячої діяльності: руховою, ігровою, мовленнєвою. Активний інтерес до питань мовленнєвого спілкування дошкільників проявляли В. Виноградов, О. Леонтьєв, Д. Ельконін, О. Левченко, М. Ільяшенко, О. Запорожець, С. Рубінштейн, Є. Тихеєва, Ф. Сохін, Л. Щерба, К. Ушинський, Л. Виготський.

Великого значення для розвитку комунікабельності у дітей старшого дошкільного віку набуває володіння мовленнєвим етикетом, який впливає на формування основ культури поведінки (Л. Дмитрук [11], Н. Михайленко [18]).

Комунікабельність $є$ однією з головних рис сучасної людини. Будучи комунікабельною людина може ефективно взаємодіяти 3 оточуючими у будь-яких ситуаціях.

Вміння спілкуватися, розмовляти грунтується на наступних соціальних навичках [9]: послідовність говоріння, врахування досвіду, вмінь, інтересів і потреб співрозмовника; уникнення домінування в розмові та перебивання співрозмовників; виявлення уваги та готовність продовжити спілкування невербальними засобами (поглядом, жестами).

Проблема формування комунікативних умінь давно почала привертати увагу багатьох дослідників - філософів, психологів, педагогів. Деякі з них звертали увагу на проблему взаємодії вихованців та вихователів (Л. Толстой, К. Ушинський, Н. Новіков, I. Бецкой). Спілкування $\epsilon$ невід'ємною частиною занять, ігор в закладі дошкільної освіти, тому формування комунікативних умінь дітей сприяє покращенню освітнього процесу.

Прагнення до комунікації - це вроджена потреба кожного. Важливо, щоб діти вміли будувати повноцінні відносини 3 однолітками, могли співчувати оточуючим і взаємодіяти з ними. Всі діти від природи товариські, але не всі діти вміють встановлювати контакт з оточуючими. Більшості дошкільникам легко вдається знайти спільну мову з людьми, та $є$ й такі яким робити це складно. На жаль, багато дітей не знають, як правильно вітатися, як підтримувати розмову, реагувати на компліменти, глузування тощо. У таких випадках слід пам'ятати про те, що варто розвивати навички комунікації.

Починати розвивати комунікабельність найкраще 3 дошкільного віку, бо він $є$ сенситивним періодом для початку формування 
багатьох рис, у тому числі і для розвитку комунікабельності дітей. Якщо ж у дитини не розвивати комунікабельність, то невміння вступати у контакт з оточуючими може негативно вплинути на іï подальше життя. Комунікабельність властива дітям, спілкування яких у сім'ї $\epsilon$ продуктивним і батьки усвідомлюють їхні комунікативні труднощі.

Важливим для розвитку комунікабельності дитини є іiі мовлення. Коло спілкування старших дошкільників розширюється, у порівнянні 3 дітьми молодшого дошкільного віку, це вимагає від дитини повноцінного оволодіння засобами спілкування. Оскільки, провідна діяльність 3 кожним віковим періодом дитини ускладнюється, то до мовлення дитини висуваються нові вимоги. Чистішою стає вимова, більш розгорнутими фрази, точніше висловлення. Діалоги дітей стають більш змістовними, включають вказівки, оцінки, узгоджуються ігрові дії. Словниковий запас дитини збільшується, засвоюються правильні граматичні конструкції. Дитина не тільки виділяє істотні ознаки в предметах і явищах, але й починає встановлювати причинно-наслідкові зв'язки між ними. Маючи досить розвинене активне мовлення, дошкільник намагається розповідати й відповідати на питання так, щоб навколишнім його слухачам було ясно й зрозуміло, що він їм хоче сказати.

Великого значення комунікабельність набуває для дітей старшого дошкільного віку. Після закінчення закладу дошкільної освіти діти потрапляють до нового колективу, переходять до першого класу школи, набувають статусу школярів. Некомунікабельним дітям складно адаптуватися до нових умов, тоді як комунікабельні швидко входять в новий колектив. Деякі діти не можуть втримати свою імпульсивність, проявляють нестриманість, а іншим складно обробляти найменшу інформацію. Частіше за все саме такі проблеми призводять до непорозуміння з однолітками, ускладнення стосунків між ними.

Проблеми розвитку комунікабельності у дітей дошкільного віку досліджуються у працях вітчизняних науковців Л. Виготського, I. Кона, А. Кошельової, Л. Стрілецької, О. Шаграєвої. Таким дослідниками як М. Лісіна, А. Рузська, Л. Галігузова та інші, була розроблена концепція комунікативної діяльності, в рамках якої вивчалося спілкування дитини з однолітками.

Для організації навчання дітей спілкуванню, щоб воно сприяло розвитку комунікабельності мовленнєвий розвиток повинен здійснюватися 3 врахуванням потенційних можливостей дитини 
раннього, дошкільного та молодшого шкільного віку. Таким чином перше місце повинен займати не програмовий зміст, а потреби дітей. Зміст цих потреб повинен бути закладений у зміст навчання [9].

Комунікабельність формується в результаті цілеспрямованого впливу на розвиток уміння дитини спілкуватися, дотримуючись правил та вимог до спілкування. Збагачення словника, оволодіння граматикою мови, а також ії фонетичними засобами $є$ необхідною умовою не лише для розвитку мислення та мовлення, але й для розвитку комунікабельності [17].

У віці від 2 до 3-х років у дітей формується потреба у спілкуванні $з$ однолітками. Діти цього віку здатні привернути до себе увагу інших, все частіше стають ініціаторами усних та фізичних контактів 3 оточуючими; починають говорити, коли настає черга. У процесі ігрових дій, дитина демонструє оточуючим свої вміння та запрошує до спільних дій інших дітей. Діти цього віку проявляють ініціативу до спільної діяльності з дорослими.

У віці від 3 до 4-х років у дітей посилюється потреба у спілкуванні з однолітками, вони стають чутливішими до них. Діти цього віку здатні дотримуватись черги, стають ініціаторами вербального спілкування використовуючи більш активні слова зі свого словникового запасу.

Дитина 4-х - 5-ти років усвідомлює своє місце та роль у групі однолітків. Дитина цього віку краще співпрацює з однолітками, використовують прямі вимоги. У них формується вибіркове ставлення до партнерів у спілкуванні.

У віці від 5 до 6-ти років діти використовують ввічливі слова, без нагадування дорослими: «вибачте», «будь ласка» і «спасибі». Провідним новоутворенням комунікативної діяльності, у цьому віці, $\epsilon$ здатність до рефлексії - орієнтація на погляд, думку, почуття інших, оцінювання себе з позиції партнерів спілкування. Це дає поштовх до розвитку комунікативних умінь. Ще одним новоутворенням $\epsilon$ антиципація - здатність передбачати можливі дії, вчинки та оцінювання з боку оточуючих, що надає спілкуванню більш усвідомленого та довільного характеру.

Дитина віком від 6-ти до 7-ми років здатна співчувати оточуючим, під час розмови використовує жести, різні пози, чекає своєї черги. Діти цього віку уважно слухають, коли інші висловлюють власну думку, підтримують і змінюють її.

Деколи складно оцінити на скільки дитина комунікабельна, складніше за все, саме батькам об'єктивно оцінити комунікабельність власної дитини, адже вона для них завжди найкраща. 
Найпростіший спосіб визначити наскільки дитина комунікабельна це поспостерігати за нею. Якщо дитина здатна без будь-яких проблем почати розмову 3 незнайомцем, познайомитися 3 однолітком, взаємодіяти з усіма учасниками колективної гри, то проблеми з комунікабельністю немає. Можна попросити дитину на ігровому майданчику взяти щось в однолітка або ж запросити інших дітей до спільної гри. Якщо дитина без будь-яких складнощів та заперечень це виконує, то це свідчить про те, що вона контактна і причин для хвилювання немає. В іншому випадку варто звернути увагу на ситуацію, що склалась і розглянути її більш детально, можливо, у дитини не достатньо розвинуті навички комунікабельності.

Перед тим, як почати розвивати комунікабельність дитини варто виявити ознаки порушення комунікації які вона має. Серед таких ознак можуть бути [10]: загальна напруженість, нервовість під час спілкування; наявне відчужене ставлення до інших; не дивляться в очі при розмові, сутуляться, недоречно посміхаються; говорять занадто швидко, дуже голосно або майже пошепки.

Проаналізувавши поведінку дітей можна зрозуміти, чому виникають проблеми комунікабельності та як їх можна подолати.

Фахівці виділяють три основні причини, які впливають на зниження або повну відсутність комунікативних навичок у дітей [10]:

1. Соціокультурні чинники - у сучасному суспільстві діє правило «кожен сам за себе». Згідно з цим правилом дитина може не бачити необхідності знаходити спільну мову з однолітками. Варто довести хибність цього твердження.

2. Внутрішньосімейні - батьки, охоплені динамічним темпом життя, мало спілкуються з дітьми, самі рідко активно комунікують. Дітям які тягнуться до однолітків, але не розуміє, як з ними знайти спільну мову слід продемонструвати приклад навичок спілкування, показати, як зацікавити інших, як підтримати бесіду.

3. Внутрішньоособистісні психологічні проблеми - тривожність, занижена самооцінка, страхи. Якщо дитина вразлива, сором'язлива або має занижену самооцінку, тоді слід тактовно показати шляхи подолання внутрішніх негараздів.

0. Денисенко виокремлює такі джерела розвитку комунікативних вмінь та навичок дітей дошкільного віку [9]:

1) дім, родина, знайомі;

2) вулиця, друзі, випадкові люди;

3) ЗДО, гуртки, секції, санаторії; 
4) засоби масової комунікації та друковані видання;

5) тварини, птахи, звуки природи, іграшкові звуки.

Навчання дітей певним навичкам комунікабельності можна поділити на три етапи:

1. Визначення навичок, які потребують розвитку.

2. З'ясування способів навчання цим навичкам.

3. Закріпляючі заняття з необхідними засобами.

Нерідко вихователі закладів дошкільної освіти розглядають навчання спілкуванню як навчання культурі поведінки. Безумовно, навички культури поведінки потрібні для побудови бесіди, але вони не можуть впливати на відносини між співрозмовниками. Зазвичай у закладах дошкільної освіти розвиток комунікабельності дітей відбувається на спеціальних заняттях, які проходять у формі ігор. Під час таких занять обов'язково залучають до діяльності неконтактних (некомунікабельних) дітей. Вихователь повинен створювати такі умови, в яких діти набували б досвіду колективного спілкування, повинен планувати спільну (колективну) роботу дітей. Саме під час такої діяльності кожна дитина може проявити себе. Такі заняття належать до непрямих методів, адже діти навіть не підозрюють, що їх навчають спілкуватися.

Можна виділити три основні шляхи, які допоможуть змінити відносини дітей з оточуючими [19]:

1. Організація гуманістичних відносин серед всіх членів даного колективу, створення атмосфери емоційного співпереживання через систему колективної діяльності, бесід.

2. Спеціальна робота, спрямована на забезпечення сприятливої позиції кожної дитини в системі внутрішньо колективних відносин.

3. Організація спеціальних занять з оволодіння інформацією про особливості людського спілкування й способами спілкування.

Не всі діти потребують допомоги під час роботи над власною комунікабельністю, до того ж певні навички спілкування, в яких варто практикуватися дитині, можуть змінюватися залежно від ії віку. Відповідно до цього, важливо знати певні норми, які відповідають певним віковим групам, а також вчасно визначати, коли і в чому дитині потрібна допомога.

Виокремлюють такі навички комунікабельності: невербальні навички, тон голосу, концентрація уваги. Для розвитку запропонованих навичок багатьма фахівцями рекомендуються певні заходи. Проаналізувавши психолого-педагогічну літератури ми виділяємо такі заходи для розвитку навичок комунікабельності: 
1. Для невербальних навичок: важливим $\epsilon$ уміння розпізнавати вирази облич, а також мову тіла співрозмовника. Для розвитку цих умінь рекомендують переглядати дитячі телевізійні передачі, мультфільми без звуку, спостерігати за поведінкою персонажів, а також промовляти, що можуть значити їх рухи. Тривалість перегляду телевізора не повинна перевищувати дві години в день. Дитина може вгадувати, що персонажі говорять, коментувати їхню міміку.

2. Для тону голосу: для того, щоб дитина вчилася розрізняти діапазони тонів, зазичай використовують диктофон, а також будьякий інший записуючий пристрій. Після того, як дорослим були записані різні «голосові емоції» дитина повинна розрізнити їх на слух. Адорослий в свою чергу повинен пояснити, як змінюється зміст сказаного разом зі зміною тону голосу.

3. Для концентрації уваги: коли дитина має певні труднощі 3 зосередженням уваги, дорослі можуть самостійно обрати будь-яку тему і промовити три фрази, де дві пов'язані з темою і одна випадкова. Потім попросити дитину обрати речення яке не стосується теми. Також дорослі можуть попросити дитину у будьякій ситуації (під час прогулянки, заняття, ігор) простежити скільки разів тема розмови змінювалась.

Важлива роль у розвитку комунікабельності дітей належить дорослим. Дорослі є прикладом для наслідування. Діти звертають більше уваги не на те, що їм говорять, а на те, як чинять самі дорослі. Виходячи з цього дорослі повинні демонструвати правильні моделі спілкування з людьми які їх оточують. Дорослим слід забути про такі фрази як: «Я зайнята», «Я не знаю» тощо, адже чим активніше заохочувати дітей до спілкування тим краще. Спільні ігри дитини і дорослого також позитивно впливають на розвиток дитячої комунікабельності. Завдяки програванню різних ситуацій і моделей поведінки вдома можливо прищепити дитині навички спілкування. Наприклад, перед тим як дитина йде на День народження до свого однолітка, можна потренуватися вітатися 3 гостями на святі, обговорити різні дискомфортні ситуації які можуть трапитися.

Навіть якщо батьки вдома будуть надавати дитині позитивні приклади спілкування, будуть грати з нею цього буде мало для того, щоб вона стала комунікабельною. Необхідно, щоб дитина мала змогу перебувати в групі інших дітей. Водіть дитину до дитячих садків, влаштовуйте дитячі свята у себе вдома. Важливо, щоб дитина могла спілкуватися та грати не лише зі своїми друзями і подружками, а й з 
малознайомими чи зовсім незнайомими дітьми. Для того, щоб дитина мала можливість спілкуватися 3 незнайомими дітьми ії можна відвести до ігрових центрів, сучасних бейбі-клубів і навіть просто піти гуляти на дитячий майданчик.

Деякі батьки припускаються помилки коли самі знаходять «гарних» друзів для своєї дитини, краще буде якщо вона сама сформує коло спілкування з тих, з ким їй цікаво. Навіть спілкування дитини 3 домашнім улюбленцем може допомогти розвинути комунікабельність.

Дуже часто діти старшого дошкільного віку можуть, без прохання дорослого, вигадати казку чи розповідь, під час розповідання вони використовують невербальні засоби спілкування, зацікавлено слухають інших, можуть самостійно використовувати аргументи та докази під час розмови з будь-ким. Часто діти старшого дошкільного віку стають ініціаторами спілкування: діляться враженнями 3 однолітками, ставлять запитання, залучають однолітків і старших до спілкування [9].

Для старших дошкільників найбільш сприятливою для розвитку комунікабельності ситуацією можна вважати ту, в якій слід партнерові по грі або дорослому щось пояснити, переконати його. Активність і самостійність у діяльності полегшує дітям засвоєння мовлення: спілкування 3 дорослими та однолітками, уміння зрозуміло висловити власне судження, супроводжувати мовленням свої дії. Завдяки цьому у старшому дошкільному віці для дитини характерна висока мовленнєва активність [9].

Отже, розвиток комунікабельності у дітей старшого дошкільного віку $\epsilon$ запорукою успішного зростання дитини як особистості. Комунікабельність формується в результаті цілеспрямованого впливу на розвиток уміння дитини спілкуватися, дотримуючись правил та вимог до спілкування. Якщо в дитинстві порушується спілкування то це призводить до втрат емоційних контактів 3 однолітками та дорослими, недорозвинення комунікативної функції мовлення, не сформованості навичок спілкування, до нездатності правильного встановлення взаємовідносин.

\section{3. Види ігрової діяльності та їх вплив на розвиток комунікабельності у дітей старшого дошкільного віку}

Необхідною умовою нормального розвитку і формування особистості дитини дошкільного віку є гра. Для дітей дошкільного віку гра $є$ ще й провідним видом діяльності. 3 точки зору психології 
гра особливо важлива для дітей раннього віку, адже саме в цей період відбувається формування психіки дитини та ії характеру. Л. Виготський, Н. Дороніна, а також інші вчені зазначали, що розвиток психічних процесів ефективніше відбувається в провідному виді діяльності. Таким чином у дітей старшого дошкільного віку комунікабельність ефективніше розвивається саме у процесі гри, ніж у будь-якій іншій діяльності.

Наведемо декілька прикладів визначень поняття «гра»: Гра - «це вид діяльності, який полягає у відтворенні дітьми дій дорослих і відносин між ними, спрямований на пізнання навколишньої діяльності» [20]; «це зусилля, яке потрібне, щоб навчитися керувати оточуючим світом, собою; здатність керувати та контролювати ситуацію, яку ми одержуємо в результаті планування та експерименту» [13]; «... вид непродуктивної діяльності, мотив якої полягає не в її результатах, а в самому процесі. Має важливе значення у вихованні, навчанні, розвитку дітей як засіб психологічної підготовки до майбутніх життєвих ситуацій ...» [3]; «форма діяльності в умовних ситуаціях, спрямованої на відтворення і засвоєння суспільного досвіду, фіксованого в соціально закріплених способах здійснення предметних дій, у предметах науки і культури» [49]; «...підпорядковане сукупності правил, прийомів або основане на певних умовах заняття, що $є$ розвагою та спортом одночасно» [4].

А. Макаренко писав: «Гра має важливе значення в житті дитини... Якою буде дитина в грі, такою вона буде і в праці, коли виросте. Тому виховання майбутнього діяча відбувається перш за все в грі...» [16].

Гра, як складна та захоплююча діяльність, вимагає великої концентрації уваги, тренує пам'ять, розвиває мислення та мовлення, сприяє процесу соціалізації особистості. Гра захоплює навіть пасивних дітей та дітей з низьким рівнем підготовки, завдяки чому їхні навчальні досягнення значно покращуються [27].

Виходячи з вище зазначених функцій ігрової діяльності можна говорити про те, що гру використовують не лише з розважальною метою. Феномен гри в тому, що будучи розвагою, відпочинком, вона здатна перерости у навчання, у творчу діяльність, у модель людських відносин.

Гру використовують з метою навчання та виховання, вона є одним із засобів розвитку дитини. Ігри супроводжують людей протягом всього їх нього дитинства, а деколи і життя. У процесі ігрової діяльності у дітей виникає потреба активно діяти 3 речами і предметами, які їх оточують. Граючи дитина може «доторкнутися» 
до світу дорослих, відчути себе на їх місці. Таким чином дитина опановує соціальні функції, різні види взаємин, пізнає щось нове, а також опановує рідну мову як засіб спілкування.

Діти старшого дошкільного віку, під час перебування в закладі дошкільної освіти, більшу частину часу грають. Зазвичай у процесі гри відбувається спілкування дошкільників. Діти старшого дошкільного віку тягнуться до своїх однолітків, їм потрібна увага оточуючих, вони хочуть щоб з ними всі дружили. Через потребу у спілкуванні 3 однолітками діти вступають у колективні ігри, виконують правила цих ігор. Гра $є$ одним з головних методів розвитку комунікабельності дошкільників, зокрема дітей старшого дошкільного віку. Основні навички спілкування, якості, які необхідні для того, щоб встановити контакт з однолітками діти дошкільного віку набувають у процесі ігрової діяльності.

Вчені подають різні класифікації ігор дітей дошкільного віку. Г. Урунтаєва [24] пропонує розрізняти два види ігор (творчі, ігри 3 правилами) та поділяти їх на підвиди.

Варто пам'ятати, що розвивати комунікабельність у дітей допомагає метод ненасильницького спілкування, а тобто спілкування без агресії. Таке спілкування ми можемо спостерігати у процесі ігрової діяльності дошкільників.

Розглянемо деякі види ігор та їх значення для розвитку комунікабельності дітей старшого дошкільного віку.

1. Сюжетно-рольові ігри.

Для дітей старшого дошкільного віку сюжетно-рольова гра $\epsilon$ головною формою дитячої самодіяльності. В. Захарченко вивчала вплив сюжетно-рольової гри на формування зв'язного мовлення у дітей старшого дошкільного віку. Вона звертала увагу на те, що сюжетно-рольові ігри містить у собі певні можливості мовленнєвого розвитку дітей дошкільного віку [13]. Оскільки комунікабельність розвивається разом з мовленням дитини то можна говорити про те, що сюжетно-рольові ігри мають певне значення і для розвитку у дітей комунікабельності.

На початку сюжетно-рольової гри діти, зазвичай, самостійно обирають ролі які їм більше подобаються. Під час таких ігор організовується міжособистісне спілкування, воно забезпечується встановленням ігрових стосунків між педагогом і дітьми на основі рольового та організаційного типів спілкування. Діти починають один з одним діалог, дають доручення та вказівки, не забувають про використання ввічливих слів. 
Граючи, наприклад, у гру «Дитячий садок» діти знають як повинен спілкуватися вихователь, няня, директор та інші працівники закладу. Тож, дитина, яка виконує роль вихователя починає діалог першою, використовує слова привітання та інші ввічливі слова (хочеться їй цього чи ні). Така дитина поводить себе так як її вихователі. Діти які дуже комунікабельні залучають до гри менш комунікабельних дітей, викликають їх на контакт.

Під час сюжетно-рольових ігор діти вирішують певні конфліктні ситуації не забуваючи про ролі які вони виконують у цій грі. Будьяка ситуація може повторюватися декілька разів, при цьому відбувається зміна ролей, таким чином, учасники повинні проявляти нові уміння у спілкуванні. Обговорення вербальної і невербальної поведінки учасників дає можливість звернути увагу на певних досягненнях або навпаки упущеннях, а також дасть можливість учасникам гри самостійно обрати шляхи корекції комунікативної діяльності.

2. Дидактичні ігри.

У основу дидактичних ігор покладено правила, які мають обов'язково дотримуватися усіма учасниками гри. Правила у таких іграх виступають головною умовою розв'язання дидактичного завдання. Зазвичай грати у ігри з правилами діти починають під керівництвом дорослого, потім вони можуть самостійно грати у ту саму гру. Починаючи зі старшого дошкільного віку діти можуть самостійно створювати нові ігри з правилами, до вже існуючих ігор діти можуть самостійно придумати нові правила. Дотримання правил у грі забезпечує колективна організація діяльності. Учасники гри (гравці) погоджують свої дії та контролюють здійснення правил однолітками.

Конкретні дії у грі зумовлюють мовленнєву активність дитини. Мовленнєво-ігрову діяльність дітей дошкільного віку досліджує А. Богуш [2]. Ученою було дібрано велику кількість мовленнєвих ігор, вправ та ситуацій. Під час будь-якої гри діти стають більш розслабленими, сміливішими, через це, вони вже можуть допомагати іншим гравцям, нагадувати їм правила гри, за необхідності виправляти. Позитивна ігрова атмосфера допомагає некомунікабельним дітям йти першими на контакт з однолітками чи дорослими.

Здійснюючи непряме керівництво грою вихователь здатний налагоджувати взаємовідносини дітей, організовуючи міжособистісні стосунки. 
3. гри драматизації.

У іграх драматизаціях діти самі зображують різноманітних героїв літературних творів, частіше за все це герої казок, пісень та віршів. У процесі такої гри дитина сама керує діями героїв, будує їх відносини. Дошкільник втілюється в образ свого героя, намагається говорити його голосом, використовує притаманні саме цьому герою інтонації.

Ігри драматизації стимулюють дітей вступати в контакт з іншими учасниками гри, передавати образ свого героя, виражати свою емоційність.

4. Ігри-фантазування.

Для ігор-фантазування важливими $є$ уява та слово. Діти за вказівками вихователя або самостійно можуть уявити казкових героїв, птахів, звірів тощо, а також наділити їх фантастичними силами, можуть створити таких героїв яких не існує. Для своїх уявних героїв діти створюють казкові сюжети. Приємні, яскраві картинки, в уяві дітей, допомагають розслабитись, подолати страхи, боязливість. Ігри-фантазування відбуваються лише за допомогою уявних образів, без підтримки ії матеріальними опорами.

Ігри-фантазування сприяють розвитку мовленнєвих здібностей дитини, розвивають навички комунікабельності. Дитину стимулюють до розповіді своєї історії, опису свого уявного персонажа. 3 захопленням дошкільник ділиться своїми фантазіями i намагається втілювати їх у реальність.

Гра підвищує активність дитини, а також вдовольняє соціальні потреби та особисті інтереси. М. Айзенбарт зазначає, що використання ігор дає змогу реалізувати низку важливих завдань 3 розвитку комунікабельності дошкільників [1]: виховання позитивного ставлення до однолітків; розвиток у дітей уміння враховувати інтереси та думки один одного, а також проявляти у вчинках толерантність і чуйність; вироблення вміння узгоджувати свої дії 3 діями товаришів; прищеплення потреби налагоджувати позитивні взаємини $з$ дорослими та ровесниками, прагнення розвивати ці відносини; відтворення дитиною в ігровій діяльності засвоєних уявлень соціального характеру і системи соціальних відносин 3 особами, які її оточують.

Вирішення описаних завдань можливе за умови використання комплексної ігрової діяльності. У процесі гри дитина у будь-якому випадку вступає у контакт з іншими учасниками цієї гри. Гра сприяє розвитку комунікабельності дітей, так як у ній створюються умови 
для розгортання особистісного та ділового спілкування, підтримки контактів з учасниками гри, обміну інформацією.

Для розвитку комунікабельності у дітей дошкільного віку варто використовувати ігрові методики які впливали б на: розвиток вміння встановлювати контакт зі співрозмовником («Як можна назвати нас по-різному?», «Сонячні зайчики», «Піраміда любові»); удосконалення спілкування без слів («Відгадай», «Хода», «Іноземець»); вдосконалення вміння чітко і ясно вимовляти слова («Як говорить казковий герой?», «Вогник мрій»).

Представлені ігри є одним із засобів активізації соціальної та комунікативної діяльності дітей старшого дошкільного віку. Розвивати комунікабельність дитини, а також підкріплювати її взаємодію з однолітками можна за допомогою класичних ігор «Імена», «Йди за лідером».

Гру «Імена» використовують для того, щоб навчити дітей привертати увагу до себе, перед тим як вони почнуть висловлювати свою думку. Усі діти стають або сідають у коло, а одна з них бере м'ячик. Дитина у якої в руках м'ячик повинна назвати ім'я будьякого гравця і кинути (підкотити) йому м'ячик. Цей гравець ловить м'ячик, а потім називає ім'я іншої дитини і передає їй м'яч. Гра продовжується доти доки не назвуть імена всіх гравців.

У грі «Йди за лідером» діти навчаються дотримуватися черги, поважати один одного та проявляти терпіння. Вихователь призначає лідером себе або будь-яку дитину. Усім іншим дають вказівки: «Наш лідер (ім'я дитини) буде виконувати дії які я буду говорити йому на вушко, а ви по черзі будете повторювати рухи за лідером». Після того, як усі діти відтворять рухи дитини-лідера обирають дитину яка найкраще копіювала рухи, вона і стає новим лідером.

За допомогою колективних ігор, тихі та спокійні діти, які зазвичай спостерігають за всіма, знаходять способи приєднатися до групи до взаємодіяти з нею. Ігрова діяльність дає можливість невпевненим в собі, боязким дітям говорити, ставити запитання, підказувати, завдяки чому і переборюється бар'єр невпевненості. У процесі колективної гри, завдяки спільному вирішенню ігрових завдань діти вчаться спілкуватися один 3 одним та враховувати думки однолітків. Емоції переживання які охоплюють учасників гри сприяють зміцненню міжособистісних відносин.

Гра допомагає дітям налагодити стосунки 3 однолітками, вихователями, батьками. У процесі гри, в закладі дошкільної освіти, 
руйнується традиційний бар'єр спілкування дітей з вихователем, створюються умови рівності в мовному партнерстві.

3 дітьми старшого дошкільного віку грають у гру «Крокодил». У процесі такої гри, діти розвивають уміння невербального спілкування. Ведучий гри за допомогою рухів тіла, міміки та жестів повинен пояснити певне слово чи дію, а завданням інших гравці уважно слідкувати за рухами ведучого і спробувати відгадати слово. Для досягнення гарних результатів у цій грі діти повинні контактувати між собою, забути про сором'язливість чи страх.

Практично всі ігри потребують мовленнєвої взаємодії між гравцями. В іграх діти опановують такі елементи спілкування: уміння почати бесіду; уміння підтримати бесіду; уміння за потреби перервати співрозмовника; уміння слухати співрозмовника; уміння погодитися 3 думкую співрозмовника; уміння спростувати думку співрозмовника; уміння доводити свою думку.

у деяких іграх діти вчаться вітатися, прощатися, дякувати та використовувати різноманітні ввічливі слова. Існують ігри у яких більше ніж половина часу відводиться для мовленнєвої практики. Діти повинні не лише уміти слухати співрозмовника, але й уміти його чути. Слухач повинен зрозуміти репліку, а також дію партнера, вміти співвіднести їх з ситуацією, правильно відреагувати на них.

Отже, можна зробити висновок, що гру використовують не лише задля розваги. На сьогодні одним з головних завдань гри є розвиток дитини. Ігри використовують задля математичного, мовленнєвого, розумового, естетичного та іншого розвитку дитини. Під час ігрової діяльності дитина може змоделювати різні ситуації життя, може намагатися знайти вихід з конфліктної ситуації, не будучи при цьому агресивною. Різноманітні види ігор впливають на розвиток дитячої комунікабельності, допомагають знаходити спільну мову 3 оточуючими, викликають бажання до спілкування, виховують повагу та інші моральні якості, допомагають соціалізуватися.

\section{Висновки}

У науковій психолого-педагогічній літературі подаються різноманітні визначення поняття «комунікабельність». Здійснивши аналіз наукової літератури ми віддаємо перевагу визначенню, яке надається у психологічному словнику, а саме, комунікабельність - це потреба і здатність особистості до спілкування з іншими людьми, товариськість.

Аналіз психолого-педагогічної та наукової літератури дозволив нам виділити певні перевагами комунікабельності та комунікабельної людини. 
Важливим для розвитку та формування особистості дитини дошкільного віку є гра. Для дітей дошкільного віку гра $є$ провідним видом діяльності. Л. Виготський, Н. Дороніна, а також інші вчені зазначали, що розвиток психічних процесів ефективніше відбувається в провідному виді діяльності. Таким чином у дітей старшого дошкільного віку комунікабельність ефективніше розвивається саме у процесі гри, ніж у будь-якій іншій діяльності.

Проаналізувавши класифікацію ігор серед різних видів ігрової діяльності, для розвитку комунікабельності у дітей старшого дошкільного віку, ми вважаємо найбільш ефективними дидактичну гру та сюжетно-рольову гру. Такі види ігор реалізують в собі розвивальну функцію, допомагають розвиткові всіх психічних процесів. У таких видах ігрової діяльності поєднується специфіка гри і навчання, що дозволяє дорослому надавати систематичний вплив в непрямій формі, найбільш відповідним віковим особливостям дітей дошкільного віку. Дидактична гра формує ігрову мотивацію, допомагає в невимушеній формі виконувати запропоновані дитині ігрові та навчальні завдання. Сюжетнорольова гра допомагає дітям вступати у контакт одне з одним, завдяки таким іграм у дітей виникає бажання спілкуватися один з одним і за межами гри.

Будь-який вид ігрової діяльності допомагає сором'язливим дітям включатися у спілкування, ставити запитання, підказувати. Вирішуючи певне завдання в грі діти вчаться спілкуватися один 3 одним та враховувати думки однолітків. Гра допомагає покращити стосунки з оточуючим. У процесі гри, створюються умови рівності в мовному партнерстві.

\section{Література}

1. Айзенбарт M., Квас 0. Організаційно-педагогічні умови формування соціально комунікативної компетенції старших дошкільників засобами ігрової діяльності. Молодь і ринок. 2015. № 7. С. 6-12.

2. Богуш А. М., Луцан Н. І. Мовленнєво-ігрова діяльність дітей дошкільного віку: мовленнєві ігри, вправи, ситуації. Київ : «Слово», 2008. $250 \mathrm{c}$.

3. Большой энциклопедический словарь / ред. А. М. Прохоров. Москва : Советская энциклопедия, 1993. 1632 с.

4. Великий тлумачний словник сучасної української мови / уклад. і голов. ред. В. Т. Бусел. Київ, Ірпінь : ВТФ «Перун», 2004. 1440 c. 
5. Вітюк Н. Р. Психологічні особливості формування комунікативних здібностей у майбутніх вчителів : автореф. дис... канд. психол. наук: 19.00.07 / Рівненський держ. гуманітарн. ун-т. Рівне, 2002. $20 \mathrm{c}$.

6. Волкова Н.П. Професійно-педагогічна комунікація : навч. посіб. Київ : ВЦ «Академія», 2006. 256 с.

7. Герасимчук А. А., Тимошенко 3. І., Шейко С. В. Філософські основи менеджменту і бізнесу : навч. посіб. Київ : Європ. ун-т, 2006. 111 с.

8. Гончаренко С. У. Український педагогічний словник. Київ : Либідь, 1997.376 с.

9. Денисенко О. І. Розвиток навичок комунікабельності у дітей дошкільного віку. Черкаси : ЧОІПОПП ЧОР, 2012. 32 с.

10. Дієві поради для розвитку комунікативних навичок. URL: https://naurok.com.ua/post/dievi-poradi-dlya-rozvitku-komunikativnihnavichok (дата звернення13.09.2021).

11. Дмитрук Л. Особливості українського мовленнєвого етикету. Науковий вісник МНУ імені В.О. Сухомлинського. Педагогічні науки. 2016. № 1 (52). С. 273-277.

12. Дьоміна Г.А. Комунікабельність як одна з найголовніших якостей сім'янина. Збірник наук. пращь Інституту психології імені Г.С. Костюка АПН України / ред. С. Д. Максименка. Т. VII. Вип. 4. Київ : «Гнозіс», 2005. С. 102-110.

13. Захарченко В. Г. Формування зв'язного мовлення дітей старшого дошкільного віку засобами сюжетно-рольової гри : автореферат дис. ... канд. пед. наук: 13.00.01. Київ, 1997. 24 с.

14. Кан-Калик В. А., Никандров Н. Д. Педагогическое творчество. Москва : Педагогика, 1990.144 с.

15. Леонтьев А. А. Психология общения. Тарту : Тарт. ун-та, 1974. $220 \mathrm{c}$.

16. Макаренко А. С. Проблеми шкільного виховання. Методика виховної роботи. Київ, 1990. С. 139-205.

17. Максименко С. Д. Загальна психологія. Київ : ЦУЛ, 2008, 271 с.

18. Михайленко Н. До проблеми формування основ культури спілкування дітей 5-7 років. Збірник наукових статей студентів спеціальності «Дошкільна освіта» / ред. О. Л. Кононко. Ніжин : НДУ ім. М. Гоголя, 2018. 147 с.

19. Мудрик А. В. Социализация человека : учеб. пособие. 2-е изд., испр. и доп. Москва : Издательский центр «Академия», 2006. 304 с.

20. Павелків Р. В., Цигипало О. П. Дитяча психологія : навч. посіб. Київ : Академвидав, 2008. 432 с. 
21. Про дошкільну освіту: Закон України від 2001, № 49. Відомості Верховної Ради України (ВВР). Дата оновлення: 20.05.2020. URL: https://zakon.rada.gov.ua/laws/show/2628-14\#Text (дата зверненя: 20.08.2021).

22. Синявський В. В., Сергєєнкова О. П. Психологічний словник. : ред. Н. А. Побірченко. Київ : Науковий світ, 2007. 274 с.

23. Теслюк В. М., Лузан П. Г. Основи педагогічної майстерності: навч. посіб. Київ : НАКККіМ, 2011. 304 с.

24. Урунтаева Г. А. Дошкольная психология. Москва : Изд. центр «Академия», 1997.336с.

25. Філоненко М. Психологія спілкування : навч. посібн. Київ : Центр учбової літератури, 2008. 224 с.

26. Ханин Ю.Л. К вопросу об оценке коммуникативности личности. Общение как предмет теоретических и прикладных исследований. Л., 1973. С. 172-173.

27. Шкваріна Т. Технологія засвоєння мовленнєвих зразків в ігровій діяльності. Дошкільне виховання. 2005. № 9. С. 18-20.

28. Шмаков С. А. Игра учащихся как педагогический феномен культуры : Дис. ... д-ра пед. наук : 13.00.01 Москва, 1997. 409 с. 